\title{
UJI AKTIVITAS LARVASIDA EKSTRAK DAUN KELADI BIRAH (Alocasia indica Schott) TERHADAP LARVA NYAMUK Culex sp.
}

\author{
Mira Susanti*, Hadi Kuncoro, Laode Rijai \\ Laboratorium Penelitian dan Pengembangan FARMAKA TROPIS, Fakultas Farmasi, \\ Universitas Mulawarman, Samarinda, Kalimantan Timur \\ *email: susantimira11@yahoo.com
}

\begin{abstract}
ABSTRAK
Telah dilakukan penelitian yang berjudul Uji Aktivitas Larvasida Ekstrak Daun Keladi Birah (Alocasia indica Schott) Terhadap Larva Nyamuk Culex sp. Penelitian ini bertujuan untuk mengetahui aktivitas larvasida terhadap larva nyamuk Culex sp. Aktivitas larvasida daun keladi birah dilihat dari kematian larva nyamuk Culex $s p$. dengan parameter $\mathrm{LC}_{50}$ dan $\mathrm{LC}_{95}$, yang dihitung dengan metode Reed and Muench. Hasil uji aktivitas larvasida yang diperoleh pada nilai $\mathrm{LC}_{50}$ untuk ekstrak kasar metanol sebesar 0,60 \%, fraksi n-heksan sebesar 0,04 \%, fraksi etil asetat sebesar $0,22 \%$ dan fraksi n-butanol sebesar $0,21 \%$. Selanjutnya, hasil uji larvasida pada nilai $\mathrm{LC}_{95}$ untuk ekstrak kasar metanol sebesar 1,06 \%, fraksi n-heksan sebesar $0,08 \%$, fraksi etil asetat sebesar $0,11 \%$ dan fraksi n-butanol sebesar 0,44 \%
\end{abstract}

Kata Kunci: Larvasida , Alocasia indica Schott, Culex sp., $L C_{50}, L C_{95}$, metode Reed and Muench

\section{PENDAHULUAN}

Larvasida merupakan suatu bahan insektisida yang mampu menghambat siklus hidup atau membunuh stadium larva pada habitat aslinya atau pada potensial habitatnya. Suatu larvasida nyamuk yang efektif harus memiliki kerja yang cepat persisten pada berbagai tempat perindukan nyamuk, baik pada air yang bersih maupun pada air yang tercemar (Haeni, 2008).

Selama ini pengendalian nyamuk sebagai vektor penyakit umumnya dilakukan dengan menggunakan pestisida sintetik. Hal ini dikarenakan pestisida sintetik dianggap efektif, praktis, manjur dan dari segi ekonomi lebih menguntungkan. Namun, hal ini perlu diwaspadai karena penggunaan pestisida sintetik secara terus menerus akan menimbulkan pencemaran lingkungan, kematian berbagai makhluk hidup lain dan menyebabkan hama pengganggu atau larva nyamuk menjadi resisten, bahkan dapat menyebabkan mutasi gen pada spesies ini. Pestisida sintetik bersifat bioaktif, mengandung bahan kimia yang sukar mengalami degradasi di alam sehingga residunya dapat mencemari lingkungan bahkan menurunkan kualitas lingkungan (Schutterer dalam Elena, 2006).

Oleh karena itu, perlu pengembangan insektisida baru yang tidak menimbulkan bahaya dan lebih ramah lingkungan, hal ini diharapkan dapat diperoleh melalui penggunaan bioinsektisida. Bioinsektisida atau insektisida hayati adalah suatu insektisida yang bahan dasarnya berasal dari tumbuhan yang mengandung bahan kimia (bioaktif) yang toksik terhadap serangga mudah terurai (biodegradable) di alam sehingga tidak mencemari lingkungan dan relatif aman bagi manusia. Selain itu insektisida hayati juga bersifat selektif (Moehammadi, 2005). 
Beberapa metabolit sekunder yang dapat memberikan efek larvasida ialah golongan senyawa alkaloid, saponin, tanin, dan flavonoid. Sebagai contoh, Mulla dkk., 2010 menjelaskan bahwa tumbuhan keladi birah (Alocasia indica Schott) memiliki kandungan metabolit sekunder golongan flavonoid. Tetapi belum banyak penelitian tentang tumbuhan ini. Selain itu, ditinjau dari pembudidayaannya tumbuhan keladi birah (Alocasia indica Schott) ini tumbuhan yang mudah tumbuh ditempat terbuka tanpa diperlukannya perlakuan khusus atau pembudidayaan sehingga peneliti tertarik untuk meneliti tumbuhan keladi birah (Alocasia indica Schott) ini terutama daunnya.

Penelitian ini bertujuan untuk melihat aktivitas larvasida daun keladi birah (Alocasia indica Schott) terhadap larva nyamuk Culex sp.

\section{METODE PENELITIAN}

\section{Bahan}

Bahan yang digunakan adalah daun tumbuhan keladi birah (Alocasia indica Schott), metanol, n-heksana, n-butanol, etil asetat, aqua destilata, dan larva nyamuk Culex sp.

\begin{abstract}
Alat
Alat yang digunakan adalah rotary evaporator (Eyela), gelas ukur (Buchi), vial/flakon, magnetic stirer (Cimarec), water bath.
\end{abstract}

\section{Prosedur Penelitian}

Penelitian dilakukan di laboratorium Laboratorium Kimia Farmasi, Fakultas Farmasi, Universitas Mulawarman, Samarinda pada bulan Oktober hingga bulan Desember 2012. Penelitian eksperimental dengan menggunakan cara pengambilan sampel Simple Random Sampling terhadap larva nyamuk Culex sp.

Daun keladi birah (Alocasia indica Schott) yang digunakan dalam penelitian ini terlebih dahulu diidentifikasi di Laboratorium Dendrologi dan Ekologi Hutan Fakultas Kehutanan Universitas Mulawarman, Samarinda.

Ekstrak daun keladi birah didapatkan dengan mengekstraksi daun keladi birah (Alocasia indica Schott) yang sebelumnya dibuat simplisia. Simplisia dimaserasi dengan pelarut metanol, setelah beberapa hari direndam maka didapatkan larutan ekstrak metanol yang kemudian dipekatkan dengan alat rotary evaporator. Larutan yang didapatkan dari pemekatan kemudian diuapkan di atas water bath. Setelah itu sebagian ekstrak yang didapatkan difraksinansi dengan metode padat-cair pada alat magnetic stirer menggunakan pelarut n-heksan, etil asetat dan n-butanol.

Konsentrasi ekstrak daun keladi birah yang digunakan pada perlakuan adalah 0,2 $\%, 0,4 \%, 0,6 \%, 0,8 \%, 1 \%, 1,2 \%$ untuk ekstrak kasar metanol. Untuk fraksi $n$ heksan adalah $0,01 \%, 0,03 \%, 0,05 \%$, $0,07 \%$ dan $0,09 \%$. Sedangkan untuk fraksi etil asetat dan $n$-butanol adalah 0,1 $\%, 0,2 \%, 0,3 \%, 0,4 \%$ dan $0,5 \%$. Konsentrasi tersebut ditetapkan berdasarkan hasil uji pendahuluan. Hewan uji yang digunakan dalam penelitian ini ialah larva nyamuk Culex sp. pada instar III-IV. Ekstrak kasar metanol dan fraksi daun keladi birah dibuat larutan stok yang telah ditentukan konsentrasinya, kemudian diencerkan dari larutan stok untuk membuat konsentrasi uji. Setelah itu larutan dalam berbagai konsentrasi 
dimasukkan kedalam botol vial yang telah berisikan larva nyamuk Culex $s p$. sebanyak 10 ekor dalam 5 replikasi. Kemudian diinkubasi selama 24 jam. Dihitung larva nyamuk Culex $s p$. yang mati kemudian ditabulasi dengan metode Reed and Muench.

\section{HASIL DAN PEMBAHASAN}

Total kematian diperoleh dengan menghitung larva yang mati pada setiap konsentrasi, dengan jumlah replikasi yang dilakukan yaitu lima kali. Kemudian dihitung persentase kematian larva dari rata-rata kematian pada tiap konsentrasi.

Peningkatan konsentrasi ekstrak kasar metanol daun keladi birah menunjukkan adanya peningkatan persentase kematian larva nyamuk Culex sp. Grafik adanya hubungan peningkatan konsentrasi ekstrak daun keladi birah dengan peningkatan kematian larva nyamuk Culex sp. disajikan dalam Gambar 1.

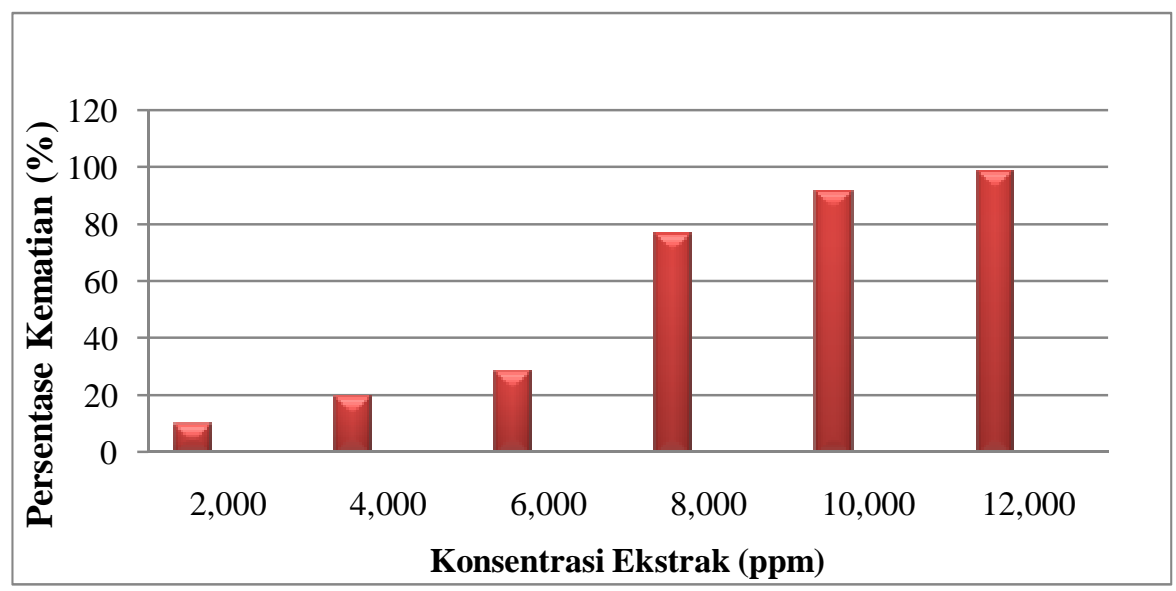

Gambar 1. Pengaruh konsentrasi ekstrak kasar metanol terhadap kematian larva nyamuk Culex sp.

Terlihat pada Gambar 1. menunjukkan peningkatan konsentrasi ekstrak kasar metanol daun keladi birah yang berbanding lurus dengan jumlah kematian dari larva nyamuk Culex sp. Berdasarkan perhitungan dengan menggunakan metode Reed and Muench, ekstrak kasar metanol daun keladi birah menunjukkan nilai $\mathrm{LC}_{50}$ sebesar 0, $60 \%$ dan nilai $\mathrm{LC}_{95}$ sebesar 1,0 $\%$ terhadap larva nyamuk Culex $s p$.

Peningkatan konsentrasi ekstrak fraksi nheksan menunjukkan adanya peningkatan kematian larva nyamuk Culex $s p$. Adanya hubungan pengaruh konsentrasi ekstrak terhadap kematian larva nyamuk Culex $s p$. disajikan dalam grafik pada Gambar 2.
Gambar 2. menunjukkan bahwa peningkatan konsentrasi ekstrak fraksi $n$ heksan berbanding lurus dengan kematian larva nyamuk Culex sp. Berdasarkan perhitungan dengan menggunakan metode Reed and Muench, ekstrak fraksi $n$-heksan daun keladi birah menunjukkan nilai $\mathrm{LC}_{50}$ sebesar 0,04\% dan nilai $\mathrm{LC}_{95}$ sebesar 0,08 $\%$ terhadap larva nyamuk Culex sp.

Peningkatan konsentrasi ekstrak fraksi etil asetat menunjukkan adanya peningkatan kematian hewan uji yaitu larva nyamuk Culex sp. Adanya hubungan pengaruh konsentrasi ekstrak fraksi etil asetat terhadap kematian larva nyamuk Culex $s p$. disajikan dalam bentuk grafik pada Gambar 3. 
Uji Aktivitas Larvasida Ekstrak Daun Keladi Birah (Alocasia indica Schott) Terhadap Larva Nyamuk Culex sp.

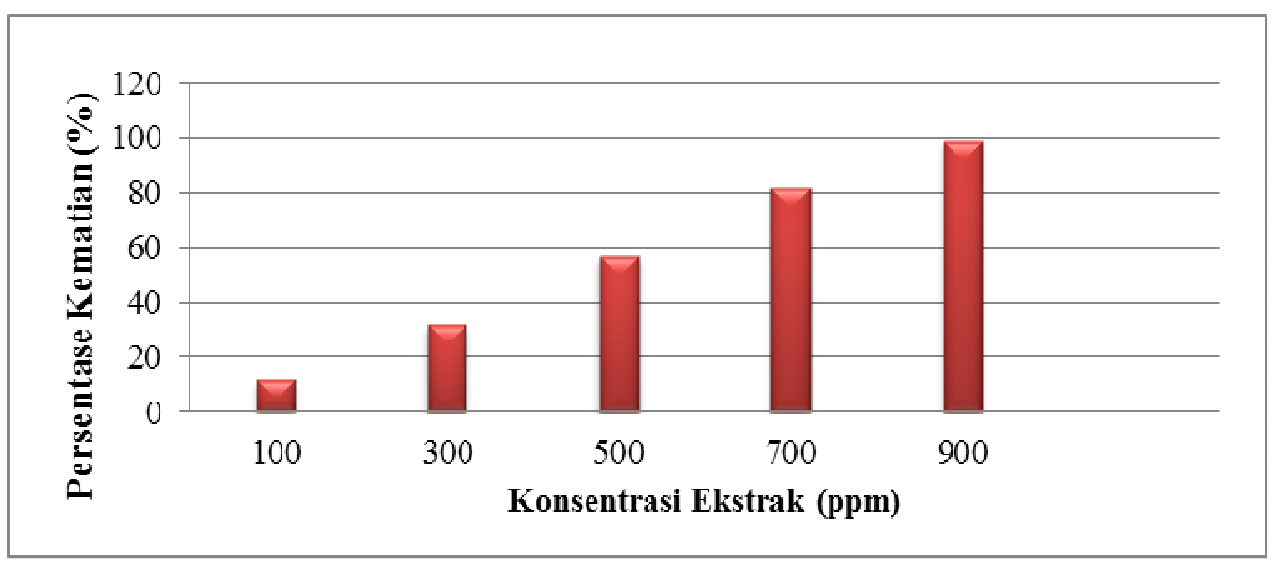

Gambar 2. Grafik pengaruh konsentrasi ekstrak fraksi n-heksan terhadap kematian larva nyamuk Culex sp.

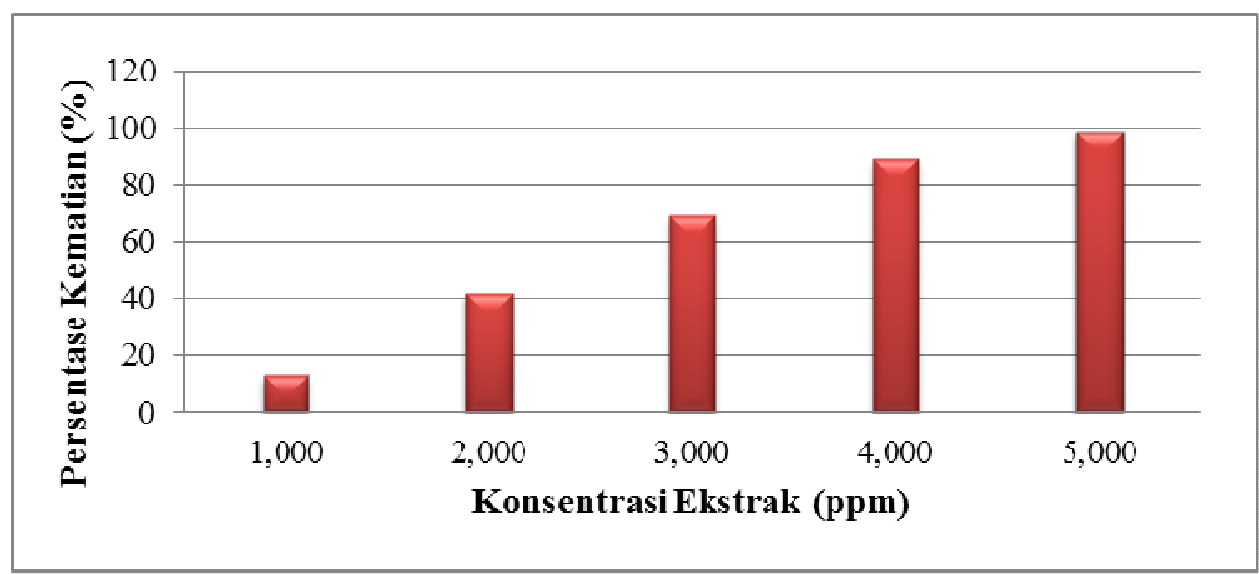

Gambar 3. Grafik pengaruh konsentrasi ekstrak fraksi etil asetat terhadap kematian larva nyamuk Culex sp.

Gambar 3. menunjukkan bahwa peningkatan konsentrasi ekstrak fraksi etil asetat berbanding lurus dengan kematian larva nyamuk Culex sp. Berdasarkan perhitungan dengan menggunakan metode Reed and Muench, ekstrak fraksi etil asetat daun keladi birah menunjukkan nilai $\mathrm{LC}_{50}$ sebesar 0,22 \% dan nilai $\mathrm{LC}_{95}$ sebesar 0,11 $\%$ terhadap larva nyamuk Culex $s p$.
Peningkatan konsentrasi ekstrak fraksi nbutanol menunjukkan adanya peningkatan kematian hewan uji yaitu larva nyamuk Culex sp. Adanya hubungan pengaruh konsentrasi ekstrak terhadap kematian larva nyamuk Culex sp. disajikan dalam bentuk grafik pada Gambar 4. 
Uji Aktivitas Larvasida Ekstrak Daun Keladi Birah (Alocasia indica Schott) Terhadap Larva Nyamuk Culex sp.

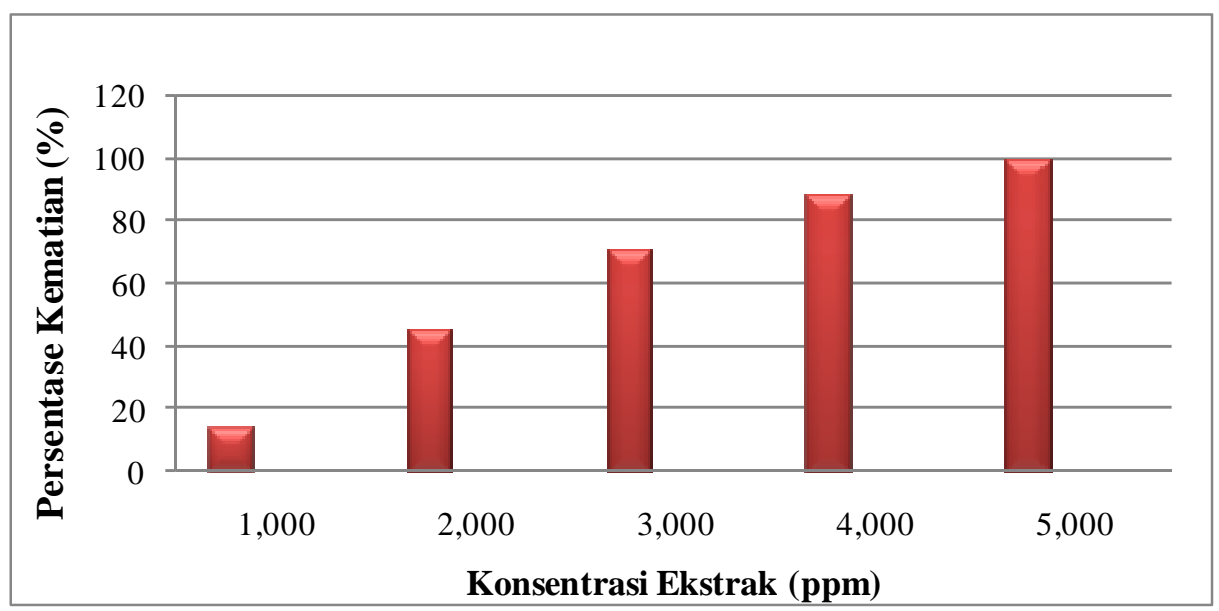

Gambar 4. Grafik pengaruh konsentrasi ekstrak fraksi n-butanol terhadap kematian larva nyamuk Culex sp.

Gambar 4. menunjukkan bahwa peningkatan konsentrasi ekstrak fraksi nbutanol berbanding lurus dengan kematian larva nyamuk Culex sp. Berdasarkan perhitungan dengan menggunakan metode Reed and Muench, ekstrak fraksi $n$-butanol daun keladi birah menunjukkan nilai $\mathrm{LC}_{50}$ sebesar 0,21\% dan nilai $\mathrm{LC}_{95}$ sebesar 0,44 $\%$ terhadap larva nyamuk Culex sp.

Perbedaan aktivitas larvasida dari masingmasing ekstrak dan fraksi daun keladi birah terhadap larva nyamuk Culex $s p$. ditunjukkan dengan perbedaan nilai $\mathrm{LC}_{50}$ dan $\mathrm{LC}_{95}$. Dari data tersebut, nilai $\mathrm{LC}_{50}$ dan $\mathrm{LC}_{95}$ daun keladi birah yang memiliki sifat larvasida paling baik terhadap kematian larva nyamuk Culex $s p$. adalah fraksi $n$-heksan dengan nilai $\mathrm{LC}_{50}$ sebesar $0,04 \%$ dan nilai $\mathrm{LC}_{95} 0,08 \%$.

Dari data tersebut dapat dilihat bahwa fraksi $n$-heksan memiliki aktivitas larvasida yang paling baik dibandingkan aktivitas larvasida ekstrak kasar metanol, fraksi etil asetat dan $n$-butanol. Hal ini kemungkinan dikarenakan jumlah kandungan senyawa yang non-polar lebih memiliki aktivitas larvasida yang lebih baik dibandingkan senyawa yang bersifat lebih polar yang terkandung pada daun keladi birah (Alocasia indica Schott).

Ekstrak kasar metanol yang memiliki aktivitas larvasida yang lebih baik dibandingkan dengan aktivitas larvasida fraksi etil asetat dan n-butanol kemungkinan dikarenakan didalam ekstrak kasar metanol senyawa-senyawa didalam ekstrak masih bercampur antara non-polar dan polar sehingga ikatan atau campuran dari kedua sifat tersebut kurang memberikan aktivitas dalam membunuh larva nyamuk Culex sp. secara maksimal.

Sedangkan ekstrak fraksi etil asetat dan nbutanol hasil dari fraksinasi yang sudah terpisah sesuai dengan sifat kelarutannya didalam masing-masing pelarutnya, sehingga senyawa-senyawa memiliki sifat berbeda akan terpisah. Namun pada pengujian nilai $\mathrm{LC}_{50}$ nilai $\mathrm{LC}_{95}$ pada fraksi etil asetat dan $n$-butanol menunjukkan aktivitas larvasida yang kurang baik dibandingkan dengan fraksi $n$-heksan, ini dikarenakan sedikitnya senyawa yang berada pada fraksi etil asetat dan $n$-butanol yang mana sedikit pula memberikan aktivitas dalam membunuh larva nyamuk Culex sp. 
Namun hasil dari pengujian yang telah dilakukan ekstrak kasar metanol dan masing-masing fraksi daun keladi birah, belum dapat dikatakan dapat digunakan sebagai larvasida alami sehingga perlu dilakukannya pengujian yang lebih lanjut. Pengujian ini dilakukan hanya sebagai screening larvasida berbahan dasar tumbuhan atau larvasida alami.

\section{KESIMPULAN}

Fraksi $n$-heksan daun keladi birah (Alocasia indica Schott) memiliki aktivitas larvasida yang lebih baik dibandingkan dengan ekstrak kasar metanol ataupun fraksi etil asetat dan fraksi $n$-butanol. Masing-masing nilai $\mathrm{LC}_{50}$ dan nilai $\mathrm{LC}_{95}$ dari fraksi $n$-heksan daun keladi birah (Alocasia indica Schott) adalah 0,04\% dan $0,08 \%$.

\section{DAFTAR PUSTAKA}

1. Elena. 2006. Pengaruh ekstrak daun Eupatorium riparium terhadap mortalitas dan perkembangan larva nyamuk Aedes aegypti. Semarang. Jurusan Biologi Fakultas MIPA UNDIP, Semarang.

2. Haeni, I. N. 2008. Uji Laboratorium Pemberian Insect Growth Regulator Pyriproxyfen terhadap Pertumbuhan dan Perkembangan Larva Aedes aegypti dan Aedes albopictus Asal Bantul, Daerah Istimewa Yogyakarta. Tesis. Yogyakarta: Universitas Gajah Mada.

3. Moehammadi, N. 2005. Potensi Ekstrak Herba Ageratum conyzoides Linn dan Daun Saccopetalum horsfieldii Benn terhadap larva nyamuk Aedes aegypti L. Jurnal Berk. Penel. Hayati.

4. Mulla Wahid, A., dkk. 2010. Evaluation of Antimicrobial Activity of Leaves Alocasia Indica Linn. International Journal of Pharmtech Research. 